\title{
Engendering Security Sector Reform: Where to from Here?
}

\author{
Daniel Bendix and Ruth Stanley*
}

\begin{abstract}
The category of gender has only recently been introduced into the debate on security sector reform (SSR). Drawing on studies of gender in SSR, this paper reviews the rationales offered for incorporating a gender perspective and the strategies adopted for achieving this. It concludes that there is still a lack of implementation tools and, furthermore, that the analysis of gender in SSR could usefully be broadened by drawing on the insights of feminist-inspired peace research on the role of security institutions in the construction of gender identities.
\end{abstract}

Keywords: Sicherheitssektorreform, Gender, Post-conflict peacebuilding

\section{Introduction}

A lthough the concept of security sector reform (SSR) was only coined some ten years ago, it has already come to occupy a central place on the development, conflict transformation and peacebuilding agenda. Broadly speaking, the security sector is understood to encompass all the organisations that have the authority to use, or order the use of, force in order to protect communities, individuals and the state. ${ }^{1}$ These include the military, police, border guards, intelligence services, government bodies that monitor such organisations, and those institutions charged with upholding the rule of law, including the judiciary and penal systems. It is also recognised that civil society organisations, international donors and the media can have an important role in SSR processes, and that private security firms and non-state armed groups need to be addressed within SSR. As this brief description indicates, SSR differs from traditional forms of military and internal security assistance in at least three important ways. First, reform of the security sector is intended not simply to enhance the efficacy of the security forces, but to ensure that they conform to standards of legality, transparency, and accountability. Secondly, and reflecting this normative impulse, SSR seeks to adopt a holistic approach, recognising that effective reform of security institutions needs to encompass the different components of the security sector in an integrated fashion. And, thirdly, SSR is concerned to have a positive impact not only on the security of the state, but also of communities and individuals, guaranteeing security provisions that are respectful of human rights and within the rule of law.

Given this attention both to normative standards, an integrated approach to the entire security sector, and the security not only of states, but also of individuals, it is remarkable that the research on and practice of SSR have only fairly recently begun to incorporate a gender dimension. The increased attention now being paid to gender aspects of SSR is reflected in the collaboration between the UN's INSTRAW (International Research and Training Institute for the Advancement of Women) and the Geneva Centre for the Democratic Control of Armed Forces (DCAF). These organizations formed a joint

\footnotetext{
* Dipl.-Pol. Daniel Bendix and Dr. Ruth Stanley are currently conducting research on security sector reform and democratic participation in a project funded by the German Foundation for Peace Research (Deutsche Stiftung Friedensforschung, DSF) (Project-No.: 001/01-2007).

1 See e.g. the articles on the concept and practice of SSR in issue 3/2005 of S+F.
}

Gender and Security Sector Working Group ${ }^{2}$, and in February 2007 initiated the project »Gender and Security Sector Reform: Creating Knowledge and Building Capacities « together with the OSCE's ODIHR (Office for Democratic Institutions and Human Rights) to produce a set of SSR tools and to hold workshops and e-discussions to highlight gender dimensions of SSR. ${ }^{3}$ This collaboration between major institutions working on advancing women's rights, democratic control of armed forces, and issues of democracy, good governance and human rights, illustrates that the issue of gender-sensitivity in SSR transcends narrow fields of expertise. ${ }^{4}$

This article first reviews the bibliography on gender in SSR, looking especially at the rationales offered for incorporating a gender dimension into SSR programmes and the proposals advanced for achieving this goal. It then reviews some practical experiences with gender and SSR, before presenting some suggestions on the way forward for a future practice of SSR that is truly engendered. ${ }^{5}$

\section{Engendering SSR: Why and How}

Why does SSR need to take gender into account? At the most basic level, it is recognised that men and women are subject to different types of insecurity, that the security sector affects men and women in different ways, and that the goal of SSR must be a security sector that ensures »the peace and wellbeing of women, men, boys and girls. « ${ }^{6}$ There is also widespread recognition of the fact that many issues which direct-

2 URL: http://www.un-instraw.org/en/index.php?option=content\&task=view \&id=1060\&Itemid=262, 20.07.2007.

3 DCAF / UN INSTRAW / OSCE-ODIHR: Project Outline - Gender and Security Sector Reform - Creating Knowledge and Building Capacities, URL http://www.dcaf.ch/gender-security-sector-reform/gssr-project-outline.pdf, 20.07.2007. The toolkit will be launched in 2008 .

4 Other organisations that work on gender and security issues without a specific focus on SSR processes include International Alert and Women Waging Peace, who have together developed a toolkit entitled »Inclusive Security - Sustainable Peace - A Toolkit for Advocacy and Action«, providing a resource base for issues relating to women, peace and security; the United Nations Development Fund for Women (UNIFEM), which contributes to UN policy and practice on demobilisation, disarmament and reintegration processes, and the Women's Network of the International Action Network on Small Arms (IANSA).

5 In the context of this brief review essay, it is not our intention to cover all the relevant bibliography, but rather to use the extant literature to highlight some main themes and findings.

6 Kristin Valasek cited in UN INSTRAW 2004: Gender and Security Sector Reform, Summary of E-Discussion, 4 October - 7 November, p. 1, URL: http://www.un-instraw.org/en/images/stories/SecuritySectorReform/ summary\%20final.pdf, 14.07.2007. 
ly affect women, girls, and marginalised men and boys have hitherto been largely neglected in SSR. ${ }^{7}$ More specifically, SSR will not fulfil its self-defined objective of ensuring democratic participation and local ownership without a gender-sensitive practice. Peace processes are generally dominated by men, with women being excluded. ${ }^{8}$

This normative argument for fully incorporating gender into SSR processes is bolstered by the fact that several international agreements mandate the inclusion of gender and women's issues into the security sector. ${ }^{9}$ Although none of these conventions and resolutions explicitly mentions SSR, Security Council Resolution 1325 has been understood as implicitly mandating the inclusion of a gender perspective in SSR processes. ${ }^{10}$ More recently, the Security Council has explicitly made the connection between SSR and gender, as it »recognize(s) the links between security sector reform and other key stabilization factors, like $[. .$.$] gender equality. { }^{11}$

Besides these normative concerns, the incorporation of a gender perspective into SSR is justified on the grounds of enhanced efficiency and effectiveness. The German Society for Technical Cooperation (GTZ) argues that gender-sensitive SSR can help to reduce the social costs of gender-related violence while simultaneously enhancing productivity by making better use of women's potentials in the labour market. ${ }^{12}$ At a more specific level, women are seen as able to perform certain security-related tasks better than men, such as screening female ex-combatants, assisting in the aftermath of sexual violence, and acting where the segregation of men and women is culturally required. ${ }^{13}$ But women are not only able to undertake specific security-related tasks that men could not perform: there is also evidence to indicate that they bring a gender-specific »value-added « to broader security tasks, such as peacekeeping and policing. The presence of women in peacekeeping operations has been found to enhance access to services by civilian women, to lower incidents of sexual misconduct and to en-

7 OECD Development Assistance Committee (DAC) 2007: OECD DAC Handbook on Security Sector Reform, Paris: OECD, p. 66; see also Farr, V. 2004: Voices from the Margins. A Response to sSecurity Sector Reform in Developing and Transitional Countries'. In: McCarthy, C./Fischer, M./Wils, O. (eds.): Security Sector Reform. Potentials and Challenges for Conflict Transformation, Berlin: Berghof Handbook for Conflict Transformation and Dialogue Series No. 2, pp. 63-70.

8 Ball, N./Brzoska, M. 2002: Voice and Accountability in the Security Sector, BICC Paper No. 21, p. 24, URL: http://www.bicc.de/publications/papers/paper21/paper21.pdf, 14.07.2007.

9 For example, the "Convention of on the Elimination of All Forms of Discrimination agains Women $(1979)$, the »Declaration on the Elimination of Violence against Women (1994), the »Bejing Declaration and Platform for Action« (1995), the »Windhoek Declaration and the Namibia Plan of Action « on Mainstreaming a Gender Perspective in Multidimensional Peace Support Operations (2000), the Security Council Resolution 1325 »Women, Peace and Security (2000), the UN General Assembly Resolution of the twenty-third special session »Further actions and initiatives to implement the Beijing Declaration and Platform for Action (2000); the Commission on the Status of Women Agreed Conclusions on »Women's equal participation in conflict prevention, management and conflict resolution and post-conflict peace-building $«(2004)$.

10 Ball/Brzoska (Note 8), p. 24

11 UN Security Council 2007: Security Sector Reform in Post-Conflict States Critical to Consolidating Peace. 5632nd meeting, URL: http://www.un.org/ News/Press/docs/2007/sc8958.doc.htm, 28.05.2007.

12 Oelke, S. 2006: Security Sector Reform and Gender. Concept and Points of Entry for Development Cooperation. Eschborn: Gesellschaft für Technische Zusammenarbeit, p. 17.

13 Valasek, K. 2007: Gender and Security Sector Reform, URL: http://www. peacewomen.org/resources/1325/Gender_ssr_dcaf07.pdf, 17.07.2007. courage the confidence and trust of civilian populations. ${ }^{14} \mathrm{~A}$ study on policing has found that female officers are less likely to use excessive or deadly force or be involved in misconduct, are more effective at defusing and de-escalating potentially violent situations, and receive more favourable evaluations and fewer citizen complaints. ${ }^{15}$

While women's access to the state security institutions is often impeded by traditional gender roles that see women as in need of protection rather than as offering necessary contributions to security forces, their role within civil society is more often highlighted as representing an important element of the security sector reform process. As civil society actors, women are credited with initiating dialogue and reconciliation processes essential to post-conflict peacebuilding. ${ }^{16}$ This often takes place at the grassroots level, as women are frequently excluded from formal SSR processes, especially at the national or international level.

Finally, it is the centrality of SSR to development, human rights and post-conflict peacebuilding that offers a compelling argument for a fully gendered perspective. This viewpoint is advanced by DCAF/UN INSTRAW/OSCE-ODIHR. In presenting their common project to highlight gender dimensions of SSR, these institutions argue that »(a)s security sector reform is increasingly recognised as a crucial part of development, peacebuilding and human rights work, it is essential that we develop the tools to successfully integrate gender into security sector reform processes $« .{ }^{17}$ SSR can be seen as a critical juncture in the reconstruction process, so that a gender-sensitive approach can contribute to the reduction of gender-based violence and discrimination, act as a catalyst to increasing the participation of women in politics in the post-war period and thus support long-term peacebuilding. ${ }^{18}$

Having recognized the need to incorporate a gender-sensitive approach into SSR, the question remains how this can best be achieved. This seems to be the crucial question, since there is an evident gap between the lip-service paid to the importance of incorporating into SSR programmes marginalized groups of society, including women and marginalized men, and the actual fulfilment of this principle in practice. ${ }^{19}$

For many scholars and practitioners, engendering SSR implies the full involvement, equal participation and representation of women in security sector institutions, security policy creation and implementation and security sector oversight. ${ }^{20}$ While this is undoubtedly a laudable goal, it is hardly a working prescription for the integration of a gender perspective, but

14 UN INSTRAW: Gender and Security Sector Reform Working Group Background Information, URL: http://www.instraw.org/en/docs/SSR/Website Background.pdf, 20.07.2007

15 Valasek (Note 13).

16 OECD Development Assistance Committee (DAC) 2005: Security System Reform and Governance, Paris: OECD, p. 18

17 DCAF/UN INSTRAW/OSCE-ODIHR 2007: Concept Note for Virtual Discussion: Integrating Gender in Security Sector Reform Assessments, Monitoring and Evaluation (M\&E), 4-29 June 2007, URL: http://www.un-instraw.org/en/ docs/SSR/VirtualDiscussionFlyer-2.pdf, 14.08.2007.

18 See e.g. Farr V. 2002: Gendering Demilitarisation as a Peacebuilding Tool BICC Paper No. 20, p. 33, URL: http://www.bicc.de/publications/papers/paper20/paper20.pdf, 25.07.2007; Oelke (Note 12), pp. 10-12.

19 See Bryden, A./N'Diaye, B./Olonisakin, F. 2005: Security Sector Governance in West Africa: Turning Principles to Practice, Geneva: DCAF ( DCAF Policy Paper No. 8), pp. 11-12.

20 OECD DAC 2007 (Note 7), p. 66, p. 105 
rather a description of an ideal state of affairs that could be the final (long-term) outcome of a gender-sensitive approach. Less ambitious recipes may be of more immediate benefit to practitioners crafting SSR programmes. In this regard, awareness-raising and gender sensitivity training among the security bodies has been highlighted as a useful approach. This includes awareness-raising with regard to gender-based violence, incorporating gender into all training curricula for the whole range of security actors, and self-help programmes and public campaigns. ${ }^{21}$ Truly effective gender-sensitivity training requires cooperation between the security sector institutions and non-state actors dealing with gender equality and gender violence in order to incorporate the expertise and insights of the latter; thus, a gender-sensitive approach to SSR would strengthen the link between state security institutions and civil society.

However, gender training can easily become merely a »superficial stamp $\ll^{22}$ if it is not embedded into a comprehensive gender mainstreaming strategy. Gender mainstreaming can broadly be defined as a strategy for making women's as well as men's concerns and experiences an integral dimension in the design, implementation, monitoring and evaluation of policies and programmes. In the SSR context, it aims to change the institutional culture of the security sector by incorporating gender-related issues at all levels and at all stages of policy planning and execution. But generally, some observe, a lack of policy articulation and practical tools hampers the implementation of gender mainstreaming in SSR processes. The recent collaborative effort between DCAF, UN INSTRAW and OSCE-ODIHR was launched to overcome such deficits.

Some authors draw attention to the fact that a state-centred security concept does not readily lend itself to a gender-sensitive approach - the more so in the post 9/11 world, where »security « has come to be associated with militarism and repression in the context of the so-called »war on terror. ${ }^{23}$ If, as noted in the introduction, individual security is implicitly included within SSR endeavours, gender practitioners tend to place special emphasis on this dimension, focussing on human security in the sense of the physical inviolability of each and every individual. They attribute a particular usefulness to the concept of human security in this restricted sense since it can help to point to »facts which are sometimes hidden behind liberalisation, democratisation and economic privatisation, such as a high rate of invisible gender-based violence in the domestic sphere, trafficking in women and children, a flourishing sex industry, etc. ${ }^{24}$ Human security, with its attention to often hidden acts of non-state (although often implicitly state-sanctioned) violence against specific groups of the population, is a concept that resonates with the subjective security needs of marginalized groups, including women.

21 Vlachová, M./Biason, L. 2003: Violence Against Women as a Challenge for Security Sector Governance. In: Hänggi, H./Winkler, T.H. (eds.): Challenges of Security Sector Governance, Münster: LIT, p. 24; Oelke (Note 12), pp. 13, 16.

22 DCAF / UN INSTRAW / OSCE-ODIHR 2007: Good and Bad Practices in Gender Training for Security Sector Personnel: Summary of a Virtual Discussion. URL: http://www.un-instraw.org/en/images/stories//gender\&ssrtra iningdiscussion-summary.pdf, 20.07.2007.

23 See e.g. Vlachová/Biason (Note 21), p. 3-7.

24 Vlachová/Biason (Note 21), p. 6.

\section{Gender in SSR Practice: Experiences on the Ground}

In view of the fact that SSR donors and practitioners have only fairly recently begun to incorporate a gender perspective, it is not surprising that there are few documented examples of the impact and outcome of engendering SSR programmes. Any assessment of the effect of such programmes is further rendered difficult by the fact that in some cases no external evaluation has been carried out; programmes reported on by those same donor agencies that designed and implemented them are, inevitably, »doomed to success. « Nevertheless, it seems useful to include some examples of attempts to include a gender-sensitive approach to SSR in order to illustrate strategies, highlight the positive effects gender-sensitive SSR can have, and point to some common problems with implementation.

The case of South Africa, whose SSR process was largely endogenously-driven, albeit with significant support from foreign donors, is often cited as a positive example of gender-sensitive reform. The involvement of women at all levels of society helped to change the focus of the South African defence reform from a technical debate to discussions on human security, militarisation, and the social and political impacts of SSR. Women members of parliament ensured that the defence review was conducted in a way that included consultations with the public and civil society actors, contributing to the success of the review by providing it with legitimacy among the people. Gender training was institutionalised for all security personnel, and women were appointed to senior positions within the ministry of defence. All in all, the objectives of gender representativity were placed very publicly on the agenda in the South African reforms. ${ }^{25}$

In the SSR process in Sierra Leone, which was largely devised by the UK's Department of International Development (DfID), gender perspectives were also incorporated. Provision was made for the appointment of women to senior positions within the armed forces and police department, a family support unit was set up which included female police personnel, leading to higher reporting rates of sexual and physical violence against women. Police were trained on how to deal with crimes of this nature. ${ }^{26}$ Despite these elements, which represent a piecemeal approach rather than a coherent overall strategy, an evaluation found that gender was not well represented in SSR in Sierra Leone. ${ }^{27}$ Two years after the transition, complaints about insensitivity to gender-based violence and the failure to investigate rape and domestic violence were fre-

25 Anderlini, S. N. 2004: Transforming the Security Sector: Women in South Africa's Transition to Democracy, Washington, D.C.: Women Waging Peace, URL: http://www.huntalternatives.org/download/9_negotiating_the_transition to democracy and reforming the_security_sector_the_vital_contributions_of_south_african_women.pdf, 14.07.2007; OECD DAC 2007 (Note 7), p. 131; Hutchful E./Fayemi, J.'K. 2005: Security System Reform in Africa. In: OECD DAC 2005 (ed.) (Note 16), p. 80.

26 Gbla, O. 2007: Security Sector Reform in Sierra Leone. In: Le Roux, L./ Kidane, Y. (eds.): Challenges to Security Sector Reform in the Horn of Africa, Tshwane: Institute for Security Studies (ISS Monograph Series 135), pp 13-36, URL: http://www.iss.co.za/dynamic/administration/file_manager/ file_links/M135FULL.PDF?link_id=31\&slink_id=4622\&link_type=12\&slink type $=13 \&$ tmpl_id=3, 14.08.2007.

27 Ball, N. et al. 2007: Security and Justice Sector Reform Programming in Africa. London: DfID (Evaluation Working Paper 23), URL: http://www.dfid. gov.uk/aboutdfid/performance/files/sjr.pdf, 10.08.2007. 
quent. ${ }^{28}$ This latter finding is open to various interpretations: it may be that the reform process opened a space where such complaints could at least be articulated, thus enabling activists to highlight gender-specific security issues. Equally, the fact that the SSR process in Sierra Leone was essentially externally-driven and thus marginalised the voices and experiences of local women probably contributed to its lack of effectivity in this regard. Vanessa Farr has found that the involvement of women in the peacebuilding process in Sierra Leone and neighbouring Liberia followed a familiar pattern: initially there was a high degree of engagement, but »once the machinery of peace begins, the impetus of women and their competencies and contributions are completely overlooked. « ${ }^{29}$ This pattern is repeated elsewhere and leads to the conclusion that women's rights and security needs can all too easily become sidelined in a technocratic, managerial approach to SSR.

Similar problems with respect to the implementation of a gender-sensitive approach have been recorded in the context of the Multi-Country Demobilization and Reintegration Programme (MDRP) for the greater Great Lakes region of Africa launched in 2002 and financed by the World Bank and 13 donors. This programme aims at providing equitable access of benefits to both male and female ex-combatants and has had some success in integrating women into the demobilisation and reintegration process. In Rwanda, the Ndabaga Women's Association of Women Ex-Combatants participated in the implementation of the programme and benefited from it, while in the Democratic Republic of Congo, women's associations were included as participants in gender-awareness raising workshops. Despite the attempt to integrate a gender perspective, however, significant under-reporting of female ex-combatants remained a problem in this case, as typical elsewhere. Among the reasons cited for this are the criteria defining combatant status, the reluctance of women and girls to report themselves as combatants and the lack of a strategy to encourage such reporting, as well as commanders' reluctance to report the presence of women and girls in their forces. ${ }^{30} \mathrm{~Pa}$ radoxically, this case illustrates the need for a gender-sensitive approach while at the same time revealing the limits of such an approach in the face of prevailing gender stereotypes.

Outside the post-conflict context, there are some examples of the fruitful involvement of civil society actors in gendersensitive security reforms. One such is the enforcement and efficacy of Malaysia's Domestic Violence Act. Findings by women's groups during the monitoring phase of this legislation with regards to the delivery of services to victims were used to advocate improvements to the legislation. ${ }^{31}$ Similar cooperation between women's organisations and government oversight agencies is reported from Cambodia in the context of monitoring compliance with Cambodia's recently adopted

28 Anderlini, S.N./Conaway, C.P. 2004: Security Sector Reform. In: International Alert/Women Waging Peace (eds.), Inclusive Security, Sustainable Peace: A Toolkit for Advocacy and Action, pp. 31-40, URL: http://www.international-alert. org/pdfs/TK10_security_sector_reform.pdf, 19.07.2007.

29 Vanessa Farr cited in UN INSTRAW 2004 (Note 7), p. 7

30 Schroeder E. 2005: Multi-Country Demobilization and Reintegration Program (MDRP) Gender Desk Study, URL: http://www.mdrp.org/PDFs/ Study_GenderDesk_En.pdf, 10.07.2007.

31 OECD DAC 2007 (Note 7), p. 117.
Law on the Prevention of Domestic Violence and the Protection of Victims. ${ }^{32}$

\section{Summary and Future Prospects}

Both the practice and analysis of gender-sensitive SSR programmes are still at an early stage. Nevertheless, a few conclusions can be drawn from the existing experiences with gender in SSR.

First, while there seems to be increasing recognition of the compelling need to incorporate a gender perspective, there is little clarity as to how this should be done and a lack of practitioners' tools to aid those involved in designing and implementing SSR; equally, there is very little independent evaluation of the strengths and weaknesses of gender-sensitive SSR approaches that could usefully be drawn on in devising future programmes. Recent initiatives to develop tools to aid practitioners are to be welcomed. They should be complemented by systematic and independent comparative evaluations of experiences with gender-sensitive SSR that would allow lessons to be drawn from policies hitherto attempted. Ideally, such research would incorporate a »before « and »after « perspective and attempt to assess the relative impact of gender-sensitive measures rather than judging them by an unattainable absolute standard of gender equality.

Secondly, available studies have a tendency to reduce "gender « to »women « and to conceptualise women essentially as peacemakers and as victims of violence. Almost entirely absent from research and policy papers on gender and SSR is a reflection on the role that specific constructions of masculinity play in prolonging or exacerbating conflict and in perpetuating unequal power relations into the post-conflict phase. This seems to be a serious problem with current conceptualisations of gender in relation to SSR. Even where analysis offers more sophisticated definitions of gender that go beyond a mere focus on women to thematise power relations between the sexes as well as the mutually-reinforcing nature of male and female gender stereotypes, these insights invariably get lost in practical policy prescriptions that focus exclusively on women. Thus, the focus on gender is all too frequently reduced to a call to empower women. While this is in itself desirable, we suggest that a genuinely gender-sensitive SSR approach needs to focus more on the role of men and the construction of masculinities. After all, the central institutions of the security sector such as the military, the police, the intelligence services, and the penal system, are almost exclusively masculine. In those countries where SSR is a particularly pressing and urgent issue, these institutions - as well as non-state violent actors - have had a profoundly negative impact on development, democracy, and human rights. This is recognised by the SSR literature - indeed, it explains why SSR has become so central a concept in development - and yet the gendered nature of the security institutions is rarely thematised. In our view, this is a major gap in the conceptualisation of the relationship between gender and SSR.

32 URL: http://www.licadho.org/programs/womanoffice.php, 14.08.2007 
Of course it has to be recognised that SSR is eminently policy-oriented and the SSR literature focuses on policy advice to major institutions and donors, making it difficult to state the case for broader transformations. Nevertheless, given that SSR programmes, especially in post-conflict situations, are viewed as critical junctures with the potential capacity to have a lasting impact on societal development, it would seem important to widen the debate on gender in SSR. The question is not merely how to guarantee women's participation in the security sector, but also how far the security institutions reflect and reinforce specific understandings of masculinity that contribute to a culture of violence and tend to exacerbate human insecurity. To give some examples: engendering police reform would imply not only setting up special units to deal with violence against women and encouraging female applicants to join the police, but also looking to see how far a macho gun culture within the police encourages a militarised style of policing that puts the lives of citizens at risk. Or, more generally: what ideal of masculinity is transmitted within the armed and security forces and how does this impact on gender relations within society as a whole? How far are men negatively impacted by dominant conceptions of masculinity in that they are required to conform to a specific understanding of what masculinity entails? In recent decades, feminist-inspired peace research literature has generated a wealth of insight into the nexus between constructions of masculinity and the state security institutions, focussing mainly on the armed forces as a crucial locus of the construction of gender identities. The incipient debate on gender in SSR could usefully build on these findings to broaden the understanding of how a gender perspective on security could contribute to societal transformation and a culture of non-violence.

\section{NEUERSCHEINUNGEN}

\section{Barbara Kauffmann}

\section{Völkerrecht/Vereinte Nationen}

Ross, Carne: Independent Diplomat. Despatches from an Unaccountable Elite. London (Hurst) 2007.

Westra, Joel: International Law and the Use of Armed Force. The UN Charter and the Major Powers. New York (Routledge) 2007.

\section{Abrüstung / Rüstungskont- rolle/ Militär/Verteidigung}

Crocker, Chester A. (Hrsg.): Leashing the Dogs of War. Conflict Management in a Divided World. Washington, DC (United States Institute of Peace Press) 2007.

Dillon, Dana R.: The China Challenge. Standing Strong Against the Military, Economic, and Political Threats that Imperil America. Lanham (Rowman and Littlefield) 2007.

\section{Nationalismus/ethnische Konflikte}

Oberschall, Anthony: Conflict and Peace Building in Divided Societies. Responses to Ethnic Violence. London (Routledge) 2007.

Washbrook, Sarah (Hrsg.): Rural Chiapas Ten Years after the Zapatista Uprising. London (Routledge) 2007.

\section{Europa/EU/Osterweiterung}

Daly, Erin/ Sarkin, Jeremy: Reconciliation in Divided Societies. Finding Common Ground. Philadelphia (University of Pennsylvania Press) 2007.

Faber, Gerrit/ Orbie, Jan (Hrsg.): European Union Trade Politics and Development. »Everything but Arms« Unravelled. London (Routledge) 2007.

Hamilton, David (Hrsg.): The New Eastern Europe. Ukraine, Belarus, Moldova. Washington, DC (Center for Transatlantic Relations) 2007.
Tudyka, Kurt P.: Die OSZE - besorgt um Europas Sicherheit. Kooperation statt Konfrontation. Hamburg (Merus-Verlag) 2007.

\section{Außen- und Sicherheits- politik allgemein}

Coleman, Katharina P.: International Organisations and Peace Enforcement. The Politics of International Legitimacy. Cambridge (Cambridge University Press) 2007.

Duffield, Mark: Global Governance and the New Wars. The Merging of Development and Security. London (Zed Books) 2007.

Klein, Ansgar/ Roth, Silke (Hrsg.): NGOs im Spannungsfeld von Krisenprävention und Sicherheitspolitik. Wiesbaden (Verlag für Sozialwissenschaften) 2007.

Schubert, Jakob von: Gewaltmonopol und Fremdherrschaft. Die militärische Intervention und Okkupation im Falle innerstaatlicher Gewalteskalation. Hamburg (Universität Hamburg, Forschungsstelle Kriege, Rüstung und Entwicklung) 2007.

\section{Sonstiges}

Brough, Michael W. (Hrsg.): Rethinking the Just War Tradition. Albany, NY (State University of New York Press) 2007.

Mouffe, Chantal: Über das Politische. Wider die kosmopolitische Illusion. Frankfurt am Main (Suhrkamp) 2007.

Chandler, David/ Heins, Volker (Hrsg.): Rethinking Ethical Foreign Policy. London Routledge, 2007.

Van Aken, Jan: Das NGO Handbuch Hamburg. Hamburg (Greenpeace Media Gmbh) 2007.

Weiss, Stefani (Hrsg.): Prekäre Staatlichkeit und internationale Ordnung. Wiesbaden (Verlag für Sozialwissenschaften) 2007. 